УДК $81.111: 81^{\prime} 42$

DOI https://doi.org/10.26661/2414-1135-2021-82-24

\title{
ПАРАВЕРБАЛЬНІ ЗАСОБИ КОМУНІКАЦІЇ У ВІЗУАЛЬНО-ГРАФІЧНОМУ РОМАНІ ВІЛЛА АЙСНЕРА «НЬЮ-ЙОРК - ВЕЛИКЕ МІСТО»
}

\author{
Матіїшин А. Я. \\ аспірантка кафедри англійської філологї \\ Прикарпатський національний університет імені Василя Стефаника \\ вул. Шевченка, 57, Івано-Франківськ, Украӥна \\ orcid.org/0000-0002-2601-1758 \\ annamatiishyn95@gmail.com
}

\author{
Ключові слова: \\ паралінгвістика, \\ мультимодальність, \\ графічний роман, шрифт, \\ вербальні компоненти, \\ невербальні компоненти.
}

У статті висвітлюється проблема використання паравербальних засобів комунікації в романі відомого американського коміксиста Вілла Айснера «Нью-Йорк - велике місто» у площині методології мультимодальності. Розглянуто поняття невербальних засобів комунікації та визначено шляхи їх проявів у романі Вілла Айснера. Здійснено комплексний аналіз шрифтів, використання кольору, позиції тексту на сторінці. Проаналізовано взаємозв'язок вербального та невербального компонентів у художньому тексті та подано приклади їх вживання. Усі текстові фрагменти супроводжуються ілюстративним матеріалом. Доведено, що використання автором різноманітних шрифтів, збільшеної гарнітури літер вказують на основні елементи мультимодального тексту. Виявлено, що для акцентуалізації сказаного автор капіталізує текст та виділяє його жирним шрифтом. Таке виділення додає більшої експресії та емоційності. Невербальний канал комунікації у візуально-графічному романі відіграє надзвичайно велику роль у сприйнятті та розумінні мультимодального тексту. Також було з'ясовано, що у візуально-графічному романі звуки передаються за допомогою вербальних засобів через фоносемантичний канал невербальної комунікації. Увесь роман написано в єдиному стилі, похилим шрифтом. Текстове повідомлення автор позиціонує на сторінці по-різному - з лівого боку, посередині та з правого боку. Таке розміщення тексту візуалізується i, як наслідок, легше сприймається читачем. Автор наближує читачів до героїв, відкриваючи їхні думки, які на сторінці зображено у спеціальних хмаринках.

Вілл Айснер висвітлює людські проблеми та переживання, тим самим демонструє реальне життя містян. Використання такого прийому вкотре доводить, що візуально-графічні романи містять серйозний контент і не створені для розваги.

Читач має володіти візуальною грамотністю, щоб правильно сприйняти та інтерпретувати мультимодальний текст. Лише в такому разі можливе продуктивне декодування. 


\title{
PARAVERBAL MEANS OF COMMUNICATION IN THE VISUAL AND GRAPHIC NOVEL "NEW-YORK: THE BIG CITY" BY WILL EISNER
}

\author{
Matiishyn A. Ya. \\ Postgraduate Student at the Department of English Philology \\ Vasyl Stefanyk Precarpathian National University \\ Shevchenko str., 57, Ivano-Frankivsk, Ukraine \\ orcid.org/0000-0002-2601-1758 \\ annamatiishyn95@gmail.com
}

Key words: paralinguistics, multimodality, graphic novel, face-type, verbal components, non-verbal components.
The article highlights the problem of using the paraverbal means of communication in the novel of the American comic book writer Will Eisner "New -York: the big city" from a multimodal perspective. The complex analysis of type-faces, use of color, position of the text on the page is carried out. The relationship between verbal and non-verbal components in the fictional text is analyzed and the examples of their use are represented. All fragments are provided with illustrative material. It is proved that the author's use of various fonts, enlarged typefaces indicate the main elements of the multimodal text. It was discovered that the author capitalizes the text and highlights the most important phrases in bold. Such accentuation adds more expression and emotionality. The non-verbal channel of communication in the visual and graphic novel plays an extremely important role in the perception and understanding of the multimodal text. It was also discovered that in the visual and graphic novel sounds are transmitted by verbal means through the phono-semantic channel of non-verbal communication. The whole novel is written in the same style, in oblique type. The author places the text message on the page in different positions - on the left side, in the middle and on the right side. Such a placement of the text is well visualized and, as a result, easily perceived by the reader. The author draws the readers closer to the characters, revealing their thoughts, which are depicted on the page in special clouds.

Will Eisner covers human problems and experiences, thus demonstrating the real life of the citizens. The use of such a method proves that the visual and graphic novels consist of serious content and are not created for entertainment. The reader must be visually literate in order to correctly perceive and interpret the multimodal text. Only in this case is productive decoding possible.
Постановка проблеми. У лінгвістичних студіях XXI століття вербальні та невербальні засоби комунікації вивчаються в межах мультимодальності [3, с. 94]. На думку Я.В. Бистрова, «... кожен текст, а особливо письмовий текст, являє собою взаємодію вербального і візуального значень, які потребують різних принципів семіотичної організації. Як наслідок, мультимодальне значення становить цілий комплекс значень, які утворюються, транслюються одиницями різних семіотичних модусів у межах мультимодального аналізу тексту» $[2$, с. 8$]$.

Окрім мультимодальної лінгвістики, невербальні засоби також досліджують у рамках кількох споріднених мовознавчих напрямів: візуальної лінгвістики, візуальної комунікації, графічної лінгвістики, паралінгвістики, комп'ютерної паралінгвістики, невербальної комунікації, невербальної семіотики, соціальної семіотики, когнітивної семіотики, лінгвістики тексту, медіалінгвістики та Інтернет-лінгвістики [3, с. 94]. Хоча багато вчених досліджують цю проблему, проте нині лишається чимало відкритих запитань щодо взаємодії вербальних та невербальних засобів комунікації у площині одного тексту, що надає актуальності пропонованому дослідженню.

Об'єктом дослідження $\epsilon$ візуально-графічний роман Вілла Айснера «Нью-Йорк - велике місто», а предметом - паравербальні засоби комунікації в романі Вілла Айснера.

Аналіз останніх досліджень і публікацій. Протягом останніх років спостерігається посилена зацікавленість вчених до міждисциплінарного й поліаспектного дослідження позамовних засобів, які знаходяться в одному комунікативному просторі. Взаємозв' язок різних семіотичних ресурсів досліджували такі науковці: О.Є. Анісімова [1], Я.В. Бистров [2], К. Джевітт [6], Г. Кресс 
[7], Т. ван Ліувен [8], Л.Л. Макарук [3], Ч. Форсевіль [5] та інші.

Постановка завдання. У статті розглядається питання паралінгвістичних засобів комунікації, які присутні в мультимодальному тексті Вілла Айснера «Нью-Йорк - велике місто». Мета статті - здійснити комплексний аналіз шрифтів, використання кольору, позиції тексту на сторінці, а також взаємозв'язок вербального та невербального компонентів художнього тексту.

Виклад основного матеріалу. Паравербальні засоби комунікації зазвичай доповнюють вербальне повідомлення, іноді заміняють пропущений вербальний компонент в усному мовленні або ж, комбінуючись із вербальними засобами, забезпечують повноту розуміння сказаного. У писемному мовленні такі засоби доповнюють написане або стають єдино можливим засобом передачі певної інформації. У візуально-графічних текстах вони відіграють надзвичайно велику роль, оскільки розкривають взаємодію вербальних та невербальних компонентів, а також їхні функції. Такі засоби $\epsilon$ важливими складниками візуально-графічного роману, оскільки збагачують його зміст.

У цій розвідці ми зосередимо увагу на елементах, які $є$ невід'ємними складниками в романі Вілла Айснера «Нью-Йорк - велике місто».

Дослідниця О.С. Анісімова зазначає: «Невербальні засоби - такі, що існують біля графемної системи мови, супроводжують вербальне мовлення та слугують для вираження різних конотацій» $[1$, с. 5$]$. Щодо писемного тексту паравербальні засоби, що визначають його внутрішню організацію, його «оптичний образ», утворюють поле паравербальних засобів тексту [1, с. 6]. До цього поля вчена зараховує «графічну сегментацію тексту і його розміщення на папері, довжину рядка, пробіли, шрифт, колір, курсив, розбивку (сторінки), стягнення, лінійні підкреслення та окреслення, типографічні знаки, графічні символи, цифри, допоміжні знаки (наприклад: §, №, $\%$ ), засоби іконічної мови (малюнок, фотографія, карикатура, таблиця, схема), незвичне написання слів і розміщення знаків пунктуації, формат паперу, ширину полів, а також інші засоби, набір яких не $\epsilon$ чітко фіксованим і може варіюватися залежно від типу конкретного тексту» [1, с. 6-7].

Усередині такого поля паравербальні засоби розрізняються [1, с. 7]:

а) ступенем своєї «прив'язаності» до вербальних засобів тексту;

б) своєю роллю в організації змістової структури тексту;

в) своїми функціями в тексті.

Усі паравербальні засоби комунікації мають різноманітне функціональне навантаження. Наприклад, використання жирного шрифту та/ чи підкреслення вказують на акцентування думок автора. Проте функціональне навантаження може змінюватися або ж розширюватися залежно від тексту [1, с. 7$]$.

Як стверджує Я.В. Бистров, «... важливим викликом мультимодальної парадигми $\epsilon$ роль адресата, який бере участь в інтерпретації значення візуальних елементів та їхньої функції у тексті» [2, с. 8]. Кожен читач розуміє все залежно від своєї уяви. Один і той самий текст сприймається всіма по-різному. У мультимодальному аналізі зазвичай виокремлюють зображення, елементи дизайну, колір, графічні засоби [2, с. 8].

Надзвичайно велику роль у мультимодальному тексті відіграють шрифти. Ними легко маніпулювати та створювати при цьому унікальні вихідні продукти.

Нині серед характерних графічних ознак шрифтів виокремлюють насиченість (жирний звичайний; темний - світлий): щзільність (стиснутий/вузький - розширений/широкий), нахил (похилий - прямий), округлість (загострений круглий), зв 'язність (зв'язаний - розділений), opiєнтацію (горизонтальна орієнтація - вертикальна орієнтація), упорядкованість (стандартний нестандартний) [2, с. 9].

У нашому дослідженні ми зосередимо нашу увагу на шрифтах, кольорі та іконічних елементах (малюнках), які автор використовує у своїй роботі. Також ми проаналізуємо ширину тексту, його розміщення на сторінці, позиціонування (горизонтальне чи вертикальне, діагональне чи довільне), виділення, вставки, підкреслення та незвичне написання слів.

Візуально-графічний роман «Нью-Йорк-велике місто» складається 3 дев'яти розділів. Кожен розділ має свою назву, яка виділена жирним шрифтом чорного кольору. Але написання заголовку першого розділу під назвою: “THE TREASURE OF

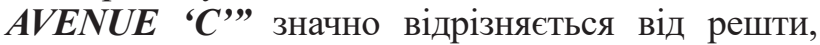
оскільки літери замальовані не в чорний колір, а білий (рис. 1) [4, с. 8]. Для першої частини заголовка автор використовує акцидентний, тобто художній вид шрифту, а для другої - антикву (iз засічками). Перша частина заголовка одразу привертає увагу читача. Основний текст, як i заголовок, розташований по ліву сторону сторінки і написаний у стовпчик, наче вірш: “FROM THE BEGINNING WHEN IT FIRST BECAME THE MAIN ARTERIAL CONNECTING THE EAST SIDE WITH THE WEST SIDE AVENUE 'C' CARRIED THE MAINSTREAM OF THE CITY - A CHANNEL IN A SEA OF CONCRETE..." [4, с. 8]. Перше слово в кожному рядку розташоване поза основним текстом, а перша літера цього слова виділена чорним жирним шрифтом. Отже, на нашу думку, автор намагається привернути увагу читача, зробивши 
акцент виділенням першої літери. Якщо добре придивитися до написання самого тексту, то можна помітити незначний нахил літер вліво. Таке розміщення мови автора на сторінці візуалізується $\mathrm{i}$, як наслідок, легше сприймається. У читача не виникає думки про вербальну надмірність тексту. Авторську нарацію доповнює малюнок, виконаний у чорно-білому кольорі з різними відтінками. Дивлячись на картинку, читач може і без тексту зрозуміти всю жалюгідність становища, в якому опинилося велике місто. На нашу думку, зображення картинки крупним планом на сторінці несе в собі психологічне навантаження, оскільки читач напружує зір, щоб роздивитися деталі, та хоче зрозуміти, що автор все-таки має на увазі.

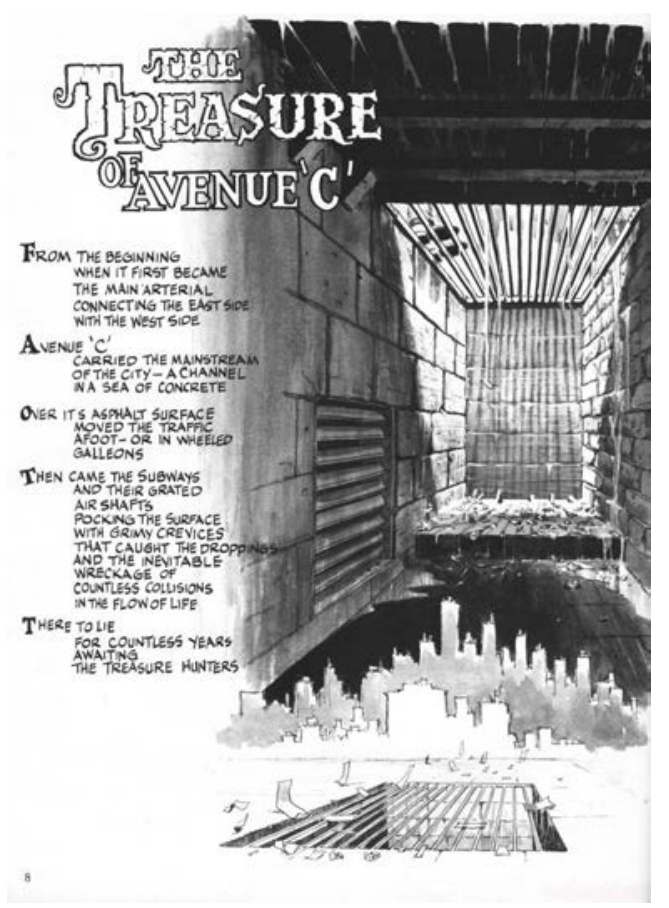

Рис. 1. Фрагмент № 1 візуально-графічного роману «Нью-Йорк - велике місто» $[4$, с. 8]

Окрім заголовка першого розділу, від решти відрізняється ще один заголовок під назвою “SUB WAYS" (рис. 2) [4, с. 27]. На сторінці він знаходиться 3 лівого боку у вигляді вивіски. Напис зафарбовано в білий колір та виділено жирним шрифтом. Якщо дивитися на загальну картинку, то читач не одразу звертає на нього увагу, адже спершу впадають в око малюнок і текст. Наратив автора знаходиться вже не 3 лівого боку, а по центру сторінки, написаний курсивом, напівжирним шрифтом великими літерами: " $A S$ THE BIG CITY CLAWS THE SKY FOR MORE LIVING SPACE SO IT BURROWS INTO THE EARTH FOR COMMUNICATION CATACOMBING ITSELF WITH CAPILLARIES THROUGH WHICH SHUTTLE THE TRAINS...” [4, с. 27]. Шрифт нагадує рукописний.
Загалом після прочитання роману можна дійти висновку, що шрифтова частина тексту витримана в одному стилі. Коментарі автора та мова героїв написані напівжирним шрифтом чорного кольору. Важливу інформацію автор виділяє жирним шрифтом та підсилює сказане окличними знаками.

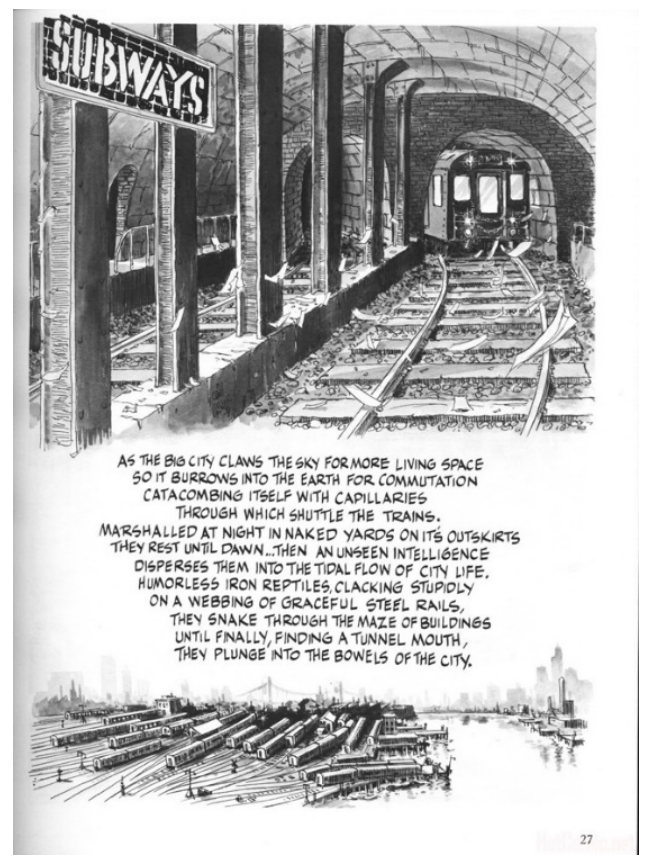

Рис. 2. Фрагмент № 2 візуально-графічного роману «Нью-Йорк - велике місто» [4, с. 27]

На рисунку (рис. 2) можна побачити, що автор доповнює своє мовлення малюнком, щоб читач міг краще зрозуміти сказане [4, с. 27]. Чорно-білі кольори гармонійно поєднуються 3 текстом та гарно сприймаються адресатом.

На наступному рисунку можна побачити зображення людей у метро. Вони не спілкуються між собою, а кожен думає щось своє (рис. 3) [4, с. 29]. Автор оформлює думки героїв у вигляді хмаринки, всередині якої знаходяться текст і картинка, яка супроводжує цей текст. Для прикладу, жінка 3 натовпу згадує слова свого чоловіка щодо розлучення: “...LET'S BE CIVILIZED ABOUT THIS, HELEN ...I WANT A DIVORCE...FACE IT ...WE'VE HAD 15 YEARS OF PURE AGONY...AGONY" $[4$, c. 29]. Коли читач погляне на обличчя цісї жінки, то побачить, що вона дуже засмучена і розчарована. Якщо розглянути чоловіка, що сидить поряд із цією жінкою, можна побачити, що він думає не вербально, а візуально. По зображенню його думок читач може здогадатися, що чоловік голодний.

Окрім тексту, автор використовує числа. Такий прийом застосовується для привернення уваги реципієнта, і авторові роману це вдається, оскільки цифри одразу привертають погляд до себе (рис. 3) [4, с. 29]. Вілл Айснер розташовує 
текст на сторінці в хаотичному порядку, ніби намагається заплутати читача. На нашу думку, в такому разі читачеві важче сконцентрувати увагу суто на чомусь одному - текстовій частині чи малюнку. Текст написаний великими літерами, напівжирним похилим шрифтом чорного кольору, що візуально сприймається приємніше. Показуючи думки героїв читачеві, автор ніби наголошує, що кожна людина живе у своєму світі, має свої проблеми та переживання. Використання такого прийому вкотре доводить, що візуально-графічні романи створені не для розваги, а містять серйозний контент. Автор висвітлює людські клопоти, тим самим демонструє реальне життя містян.

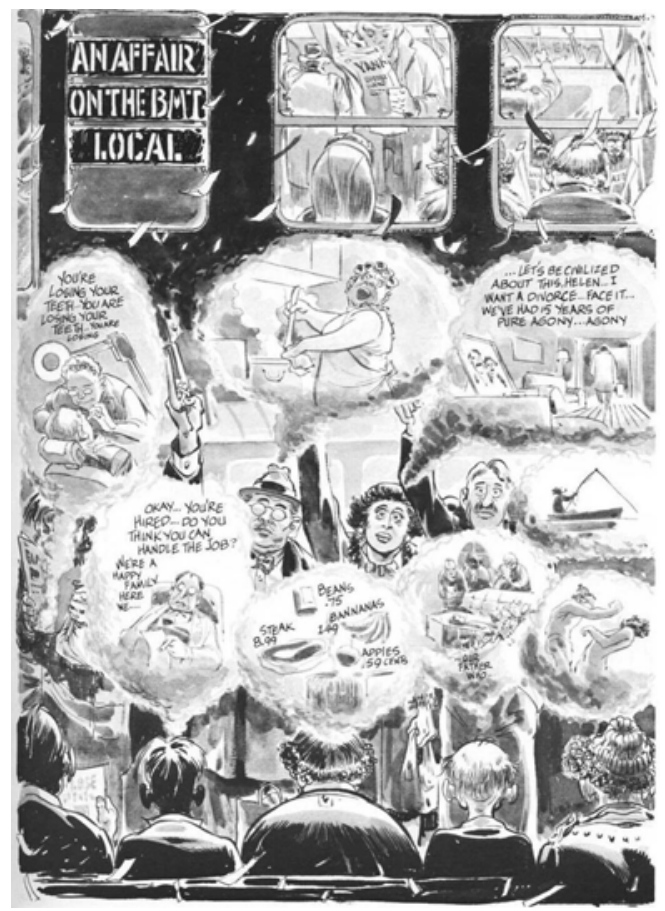

Рис. 3. Фрагмент № 3 візуально-графічного роману «Нью-Йорк - велике місто» $[4$, с. 29]

У романі також можна простежити поєднання автором різних літер, які передають звуки, тобто звуконаслідування (рис. 4) [4, с. 54]. Так письмова мова може сприйматися акустично. У візуально-графічних текстах звуки передаються за допомогою вербальних засобів через фоносемантичний канал невербальної комунікації.

Жирне та напівжирне виділення шрифту та капіталізація здійснюють акцент на вибрані фрагменти (рис. 4) [4, с. 54]. На зображенні видно, що звуки “HONK”, "RRRRR", "BEEP”, “WHEEEO”, “CLANG” з'являються поблизу об'єктів, які їх створюють [4, с. 54]. Так, сигнали автомобілів автор передає звуком “HONK”, який на картинках виділяється за допомогою збільшеної гарнітури літер білого та чорного кольорів [4, с. 54]. Фоносемантичні засоби "CLANG" та "RRRR" $€$ вираженням брязкотіння предметів, загального шуму вулиць Нью-Йорка [4, с. 54]. Про наближення потяга наратор повідомляє появою звуку "SCREECH" [4, c. 54]. Малюнок доповнюе всю картину і дає читачеві чітко зрозуміти, що відбувається в момент мовлення героїв. На нашу думку, без візуального доповнення такі звуки не мали $б$ жодного смислового навантаження. На фоні «голосу» міста митець привертає увагу реципієнта до мовлення героїв, виділяючи фрази жирним шрифтом чорного кольору: “ОH, NO HERBIE... IVE GOT NOBODY SPECIAL...YOU?? ARE YOU MARRIED, OR SOMETHIN?" [4, c. 54]. Таке виділення тексту додає більшої експресії та емоційності. Паузи в мовленні героїв Вілл Айснер позначає трьома крапками.

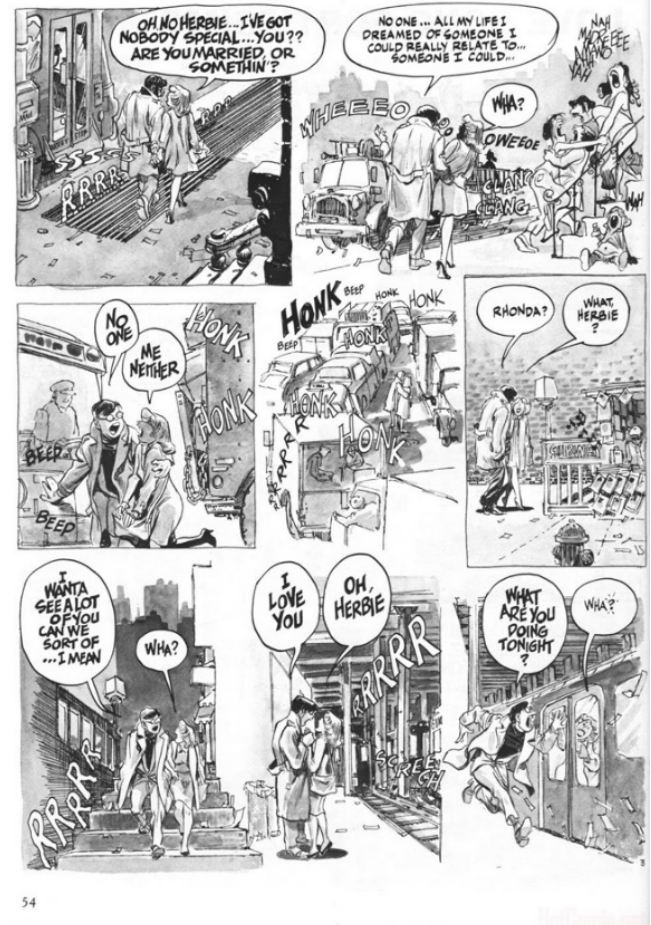

Рис. 4. Фрагмент № 4 візуально-графічного роману «Нью-Йорк - велике місто» $[4$, с. 54]

Висновки та перспективи подальших досліджень. Зробивши аналіз графічного роману «НьюЙорк - велике місто», доходимо висновку, що цей твір багатий на паравербальні засоби передачі інформації. Автор капіталізує, виокремлює та виділяє важливі думки жирним шрифтом, у деяких випадках збільшує гарнітуру для акцентуалізації. Увесь роман написаний в єдиному стилі - великими літерами, похилим шрифтом (окрім заголовків історій). Вербальна частина постійно супроводжується візуальними компонентами і навпаки. В окремих епізодах автор подає лише картинки з мінімальною кількістю тексту, проте це не заважає розумінню інформації. Усі малюнки, які супроводжують текст, 
виконані в чорно-білому кольорі 3 різними відтінками. Текстове повідомлення автор позиціонує на сторінці по-різному - 3 лівого боку, $з$ правого боку або ж посередині. На нашу думку, читач має володіти візуальною грамотністю, щоб правильно сприйняти та інтерпретувати текстове повідомлення. Лише в такому разі можливе продуктивне декодування.

Перспективу подальших досліджень вбачаємо в докладному вивченні паравербальних засобів комунікації та їхніх взаємозв'язків у візуально-графічних романах.

\section{ЛІТЕРАТУРА}

1. Анисимова Е.Е. Лингвистика текста и межкультурная коммуникация (на материале креолизованных текстов) : учебное пособие для студентов факультетов иностранных языков. Москва : Издательский центр «Академия», 2003. $128 \mathrm{c}$.

2. Бистров Я. Взаємодія вербального і графічного модусів у художньому тексті (мультимодальний підхід). Науковий вісник Херсонського держсавного університету. Серія «Перекладознавство та міжкультурна комунікаиія». 2018. Вип. 4. С. 7-12.

3. Макарук Л.Л. Паралінгвальні засоби як композиційні складники сучасних англомовних мультимодальних текстів. Актуальні питання іноземної філології. 2016. № 4. С. 94-98.

4. Eisner W. New York, the big city. DC Comics, New York, 2000. 144 p. URL: https://www. zipcomic.com/new-york-the-big-city

5. Forceville C. Non-verbal and multimodal metaphor in a cognitivist framework: Agendas for research. Cognitive Linguistics: Current Applications and Future Perspectives / ed. by G. Kristiansen, M. Achard, R. Dirren and de Mendoza Ibáñez, F.R. Berlin; N. Y.: Mouton de Gruyter, 2006. P. 379-402.

6. Jewitt C. The Routledge Handbook of Multimodal Analysis. London : Routledge, 2009. 340 p.

7. Kress G. Multimodality: A Social Semiotic Approach to Contemporary Communication. $1^{\text {st }}$ ed. London : Routledge, 2009. 236 p.
8. Leeuwen Theo Van. Multimodality. The Handbook of Discourse Analysis / ed. by Tannen Deborah, Hamilton E. Heidi, Schiffrin Deborah. Oxford : Wiley Blackwell, 2015. Vol. 2. P. 447-465.

\section{REFERENCES}

1. Anisimova E.E. (2003). Textual linguistics and intercultural communication (based on creolized texts) [Lingvistika teksta i mezhkul'turnaja kommunikatsija (na materiale kreolizovannykh tekstov)]. Moskva: Academia, $128 \mathrm{p}$.

2. Bystrov Ya. (2018). Interplay of verbal and typographic modes in the fictional text. A multimodal approach. [Vzaiemodiia verbalnoho i hrafichnoho modusiv u khudozhnomu teksti (multymodalnyi pidkhid)]. Naukovyi visnyk Khersonskoho derzhavnoho universytetu. Seriia «Perekladoznavstvo ta mizhkulturna komunikatsiia». Vol. 4. Pp. 7-12.

3. Makaruk L.L. (2016). Paralingual elements as building blocks of contemporary English-language multimodal texts. [Paralinhvalni zasoby yak kompozytsiini skladnyky suchasnykh anhlomovnykh multymodalnykh tekstiv]. Aktualni pytannia inozemnoi filolohii. Vol. 4. pp. 94-98.

4. Eisner W. (2000). New York, the big city. DC Comics, New York. 144 p.

5. Forceville C. (2006). Non-verbal and multimodal metaphor in a cognitivist framework: Agendas for research. Cognitive Linguistics: Current Applications and Future Perspectives / ed. by G. Kristiansen, M. Achard, R. Dirren and de Mendoza Ibáñez, F.R. Berlin; N. Y.: Mouton de Gruyter. pp. 379-402.

6. Jewitt C. (2009). The Routledge Handbook of Multimodal Analysis. London: Routledge. 340 p.

7. Kress G. (2009). Multimodality: A Social Semiotic Approach to Contemporary Communication. $1^{\text {st }}$ ed. London: Routledge. $236 \mathrm{p}$.

8. Leeuwen Theo Van. (2015). Multimodality. The Handbook of Discourse Analysis / ed. by Tannen Deborah, Hamilton E. Heidi, Schiffrin Deborah. Oxford. Wiley Blackwell. Vol. 2. pp. 447-465. 